\title{
The effects of water temperature on physiological responses and exercise performance during immersed incremental exercise
}

\author{
Tomomi Fujimoto $^{1 *}$, Yosuke Sasaki ${ }^{1}$, Hitoshi Wakabayashi ${ }^{2}$, Yasuo Sengoku ${ }^{3}$, Shozo Tsubakimoto ${ }^{3}$, \\ Takeshi Nishiyasu ${ }^{3}$
}

From 15th International Conference on Environmental Ergonomics (ICEE XV)

Portsmouth, UK. 28 June - 3 July 2015

\section{Introduction}

Aquatic exercise such as swimming is performed in the water of 18 to $34{ }^{\circ} \mathrm{C}$ because of the differences in ambient environmental conditions. Heat conductivity of water is greater than that of air, therefore water temperature would have a considerable impact on physiological responses and exercise performance. A previous study has shown that, oxygen consumption $\left(\mathrm{V}(\cdot) \mathrm{O}_{2}\right)$ during immersed cycle exercise at submaximal workload is greater in cold water $\left(18{ }^{\circ} \mathrm{C}\right)$ compared to moderately cool and warm water $\left(25\right.$ and $\left.34{ }^{\circ} \mathrm{C}\right)$ [1]. Furthermore, previous studies have reported decreased $\mathrm{V}(\cdot) \mathrm{O}_{2}$ at maximal work $\left(\mathrm{V}(\cdot) \mathrm{O}_{2 \text { peak }}\right)$ in the cold water [2], while others have reported no change [3]. Therefore, consensus views on whether difference in water temperature affects $\mathrm{V}(\cdot)$ $\mathrm{O}_{2 \text { peak }}$ and exercise performance hasn't been obtained. The purpose of this study was to investigate the effects of water temperature on physiological responses and exercise performance using immersed incremental cycle exercise until exhaustion.

\section{Methods}

Ten healthy young men performed incremental exercise on a water cycle ergometer in a semi-recumbent position. The subjects immersed to their shoulders and performed the exercise in 3 water temperatures (Tw): 18, 26 and $34{ }^{\circ} \mathrm{C}$. For the exercise, initial workload was $60 \mathrm{~W}$ and increased $20 \mathrm{~W}$ every 2 minutes at first 4 levels, and then increased $10 \mathrm{~W}$ every minute until they would no longer continue. The workload was increased by electrical brake

\footnotetext{
* Correspondence: swimmer_tomomi@yahoo.co.jp

'Graduate School of Comprehensive Human Sciences, University of Tsukuba, Japan

Full list of author information is available at the end of the article
}

whilst keeping a constant pedalling rate $(60 \mathrm{rpm})$ in an attempt to avoid changes in the water external force exerted on the legs. Oesophageal temperature, skin temperature, expired gases, heart rate and maximal workload were measured. This research conformed to the principles of the Declaration of Helsinki, and all subjects signed an informed consent form.

\section{Results}

During submaximal exercise (60 to $120 \mathrm{~W}$ ), $\mathrm{V}(\cdot) \mathrm{O}_{2}$ was higher in $\mathrm{T}_{\mathrm{w}} 18$ compared to other conditions $\left(\mathrm{T}_{\mathrm{w}} 26\right.$ and 34). While maximal workload in $\mathrm{T}_{\mathrm{w}} 18$ was lower than in the other conditions $\left(\mathrm{T}_{\mathrm{w}} 18\right.$ mean (SD): 138(16) W, $\mathrm{T}_{\mathrm{w}}$ 26: 157(15) W, $\mathrm{T}_{\mathrm{w}}$ 34: 156(18) W), $\mathrm{V}(\cdot)$ $\mathrm{O}_{2 \text { peak }}$ did not differ among conditions $\left(\mathrm{T}_{\mathrm{w}} 18: 3156\right.$ (364) $\mathrm{mL} \cdot \mathrm{min}^{-1}, \mathrm{~T}_{\mathrm{w}}$ 26: 3270(344) mL. $\mathrm{min}^{-1}, \mathrm{~T}_{\mathrm{w}}$ 34: 3281(268) $\left.\mathrm{mL} \cdot \mathrm{min}^{-1}\right)$. Minute ventilation during maximal and submaximal exercise and tidal volume during submaximal exercise were higher in $\mathrm{T}_{\mathrm{w}} 18$ compared to the other conditions, while respiratory frequency did not differ between conditions.

\section{Discussion}

The lower maximal workload in $\mathrm{T}_{\mathrm{w}} 18$ may be due to the fact that, even though $\mathrm{V}(\cdot) \mathrm{O}_{2 \text { peak }}$ was same level among all conditions, it reached peak values faster in $\mathrm{T}_{\mathrm{w}} 18$ compared to the other conditions, since $\mathrm{V}(\cdot) \mathrm{O}_{2}$ in $\mathrm{T}_{\mathrm{w}} 18$ during submaximal exercise was already elevated. The enhanced ventilatory response in $\mathrm{T}_{\mathrm{w}} 18$ was the result of the enhanced tidal volume rather than respiratory frequency. 


\section{Conclusion}

During immersed incremental cycle exercise, exercise performance decreases in cold water $\left(18{ }^{\circ} \mathrm{C}\right)$ due to $\mathrm{V}(\cdot)$ $\mathrm{O}_{2}$ reaching peak values faster. Ventilatory response $(\mathrm{Vt})$ is enhanced in cold water $\left(18{ }^{\circ} \mathrm{C}\right)$.

\section{Authors' details}

${ }^{1}$ Graduate School of Comprehensive Human Sciences, University of Tsukuba, Japan. ${ }^{2}$ Faculty of Engineering, Chiba Institute of Technology, Japan.

${ }^{3}$ Institute of Health and Sport Sciences, University of Tsukuba, Japan.

Published: 14 September 2015

\section{References}

1. McArdle WD, Magel JR, Lesmes GR, Pechar GS: Metabolic and cardiovascular adjustment to work in air and water at 18,25 , and 33 degrees C. J Appl Physiol 1976, 40:85-90.

2. Rennie DW, Park Y, Veicsteinas A, Pendergast DR: Metabolic and circulatory adaptation to cold water stress. Exercise Bioenergetics and Gas Exchange 1980, 315-321.

3. Dressendorfer RH, Morlock JF, Baker DG, Hong SK: Effects of head-out water immersion on cardiorespiratory responses to maximal cycling exercise. Undersea Biomed Res 1976, 3:177-87.

doi:10.1186/2046-7648-4-S1-A37

Cite this article as: Fujimoto et al:: The effects of water temperature on physiological responses and exercise performance during immersed incremental exercise. Extreme Physiology \& Medicine 2015 4(Suppl 1):A37.

\section{Submit your next manuscript to BioMed Central} and take full advantage of:

- Convenient online submission

- Thorough peer review

- No space constraints or color figure charges

- Immediate publication on acceptance

- Inclusion in PubMed, CAS, Scopus and Google Scholar

- Research which is freely available for redistribution

Submit your manuscript at www.biomedcentral.com/submit
(Ciomed Central 